\title{
KARAKTERISTIK PEMBAKARAN BIOBRIKET CAMPURAN BATUBARA DAN SABUT KELAPA
}

\author{
Amin Sulistyanto \\ Jurusan Teknik Mesin Fakultas Teknik Universitas Muhammadiyah Surakarta \\ Jl.A.Yani Tromol Pos1 Pabelan Kartasura
}

\begin{abstract}
ABSTRAK
Potensi biomass sabut kelapa sebagai sumber energi alternatif sedemikian melimpah, namun belum terolah sepenuhnya. Tujuan penelitian ini adalah menguji karakteristik pembakaran biobriket campuran batubara dengan sabut kelapa perbandingan batubara : biomass : 10\% : 90\%, 20\% : 80\%, 30\% : 70\%.Penelitian awal dilakukan dengan pengujian proximate bahan baku meliputi kadar air, nilai kalor, kadar abu, volatile matter dan kadar karbon Selanjutnya dilakukan pembuatan biobriket dengan pencampuran bahan baku batu bara, sabut kelapa, lime stone dengan perekat pati kanji dengan pengepresan tekanan $100 \mathrm{~kg} / \mathrm{cm}^{2}$ Pengujian karakteristik pembakaran dilakukan dengan alat uji pembakaran di Laboratorium Teknik Mesin Universitas Muhammadiyah Surakarta untuk mengetahui besarnya laju pengurangan massa dengan kecepatan udara konstan. Pengujian emisi polutan hasil pembakaran dilakukan di Laboratorium Dinas Perhubungan Rembang Berdasarkan percobaan dan parameter yang telah di uji, penambahan biomass menyebabkan naiknya volatile matter sehingga lebih cepat terbakar dan laju pembakaran lebih cepat. Penambahan biomass juga dapat menurunkan emisi polutan yang dihasilkan pada saat pembakaran. Komposisi biobriket terbaik yang dapat digunakan untuk kebutuhan sehari-hari adalah komposisi batubara : biomass $=10 \%: 90 \%$ karena lebih cepat terbakar dan lebih ramah lingkungan, sedangkan untuk kebutuhan industri, komposisi terbaik dengan pencapaian temperatur tertinggi adalah komposisi batubara : biomass $=30 \%$ : $70 \%$.
\end{abstract}

Kata kunci : Sabut kelapa, biobriket, karakeristik pembakaran , polutan.

\section{PENDAHULUAN}

Tingkat pemakaian bahan bakar terutama bahan bakar fosil di dunia semakin meningkat seiring dengan semakin bertambahnya populasi manusia dan meningkatnya laju industri di berbagai negara di dunia. Hal tersebut menimbulkan kekhawatiran akan terjadinya krisis bahan bakar. Di samping itu kesadaran manusia akan lingkungan semakin tinggi sehingga muncul kekhawatiran meningkatnya laju pencemaran lingkungan terutama polusi udara yang diakibatkan oleh pembakaran bahan bakar tersebut, sehingga muncul sebuah pemikiran penggunaan energi alternatif yang bersih.

Beberapa jenis sumber energi alternatif yang bisa dikembangkan antara lain : energi matahari, energi angin, energi panas bumi, energi panas laut (OTEC) dan energi biomassa. Diantara sumber-sumber energi alternatif tersebut, energi biomass 
merupakan sumber energi alternatif yang perlu mendapat prioritas dalam pengembangannya dibandingkan dengan sumber energi yang lain. Di sisi lain, Indonesia sebagai negara agraris banyak menghasilkan limbah pertanian yang kurang termanfaatkan. Limbah pertanian yang merupakan biomass tersebut merupakan sumber energi alternatif yang melimpah, dengan kandungan energi yang relatif besar. Limbah pertanian tersebut apabila diolah bersama-sama dengan batu bara dan zat pengikat polutan akan menjadi suatu bahan bakar padat buatan yang lebih luas penggunaannya sebagai bahan bakar alternatif yang di sebut biobriket.

Di samping itu sumber energi biomassa mempunyai keuntungan pemanfaatan (Syafii, 2003) antara lain :

1. Sumber energi ini dapat dimanfaatkan secara lestari karena sifatnya yang renewable resources.

2. Sumber energi ini relatif tidak mengandung unsur sulfur sehingga tidak menyebabkan polusi udara sebagaimana yang terjadi pada bahan bakar fosil.

3. Pemanfaatan energi biomassa juga meningkatkan efisiensi pemanfaatan limbah pertanian.

Berdasarkan hal tersebut di atas, maka peneliti melakukan penelitian tentang pengolahan limbah pertanian (dalam penelitian ini peneliti memanfaatkan limbah pertanian berupa sabut kelapa) menjadi biobriket sebagai salah satu bahan bakar alternatif.

Dalam makalah ini akan dilakukan pembahasan mengenai pengaruh variasi komposisi biobriket terhadap laju pengurangan massa pada proses pembakaran biobriket serta dampak polutan yang dihasilkan dari proses pembakaran biobriket terhadap lingkungan.

Adapun biomass yang digunakan dalam penelitian ini adalah sabut kelapa dengan pertimbangan murah, mudah didapatkan dan belum termanfaatkan maksimal.

\section{TINJAUAN PUSTAKA}

Tahapan dalam pembakaran bahan bakar padat adalah sebagai berikut :

1. Pengeringan

Dalam proses ini bahan bakar pengalami proses kenaikan temperatur yang akan mengakibatkan menguapnya kadar air yang berada pada permukaan bahan bakar tersebut, sedangkan untuk kadar air yang berada di dalam akan menguap melalui pori-pori bahan bakar padat tersebut.

2. Devolatilisasi

Yaitu proses bahan bakar mulai mengalami dekomposisi setelah terjadi pengeringan.

3. Pembakaran Arang

Sisa dari pirolisis adalah arang (fix carbon) dan sedikit abu, kemudian partikel bahan bakar mengalami tahapan oksidasi arang yang memerlukan $70 \%$ $80 \%$ dari total waktu pembakaran.

Faktor-faktor yang mempengaruhi pembakaran bahan bakar padat, antara lain :

1. Ukuran partikel

Partikel yang lebih kecil ukurannya akan lebih cepat terbakar.

2. Kecepatan aliran udara Laju pembakaran biobriket akan naik dengan adanya kenaikan kecepatan aliran udara dan kenaikan temperatur

3. Jenis bahan bakar

Jenis bahan bakar akan menentukan karakteristik bahan bakar. Karakteristik tersebut antara lain kandungan volatile matter dan kandungan moisture.

4. Temperatur udara pembakaran Kenaikan temperatur udara pembakaran menyebabkan semakin pendeknya waktu pembakaran.

Beberapa masalah yang berhubungan dengan pembakaran sabut kelapa dengan batubara antara lain :

a. Kadar air 
Kandungan air yang tinggi menyulitkan penyalaan dan mengurangi temperatur pembakaran.

b. Kadar kalori

Semakin besar nilai kalor maka kecepatan pembakaran semakin lambat.

c. Kadar abu

Kadar abu yang tinggi didalam batubara tidak mempengaruhi proses pembakaran. Kadar abu yang tinggi dalam batubara akan mempersulit penyalaan batubara.

d. Volatile matter atau zat-zat yang mudah menguap

Semakin banyak kandungan volatile matter pada biobriket maka semakin mudah biobriket untuk terbakar dan menyala.

e. Bulk density

Sabut kelapa mempunyai bulk density yang jauh lebih rendah bila dibandingkan dengan batubara.

\section{Jenis Polutan Yang Dihasilkan Pada Pembakaran Bahan Bakar}

Secara teoritis pembakaran bahan bakar menghasilkan $\mathrm{CO}_{2}$ dan $\mathrm{H}_{2} \mathrm{O}$ saja, padahal kenyataannya pembakaran pada bahan bakar banyak yang tidak sempurna dimana akan menimbulkan zat-zat polutan yang berbahaya terhadap kesehatan manusia. Adapun beberapa polutan dari bahan bakar antara lain : Sulfur Dioksida $\left(\mathrm{SO}_{\mathrm{x}}\right)$, Carbon Monoksida (CO), Oksida nitrogen $\left(\mathrm{NO}_{\mathrm{x}}\right)$, Oksidan $\left(\mathrm{O}_{3}\right)$, Hidrokarbon $(\mathrm{HC})$, Khlorin ( $\mathrm{Cl}_{2}$ ), Partikel Debu, Timah Hitam $(\mathrm{Pb})$, Besi (Fe).

\section{Sabut Kelapa}

Sabut kelapa merupakan bagian dari kelapa yang termasuk dalam familia palmae. Sabut kelapa merupakan bagian yang cukup banyak dari buah kelapa, yaitu kurang lebih $35 \%$ dari berat keseluruhan buah.

\section{Perekat Pati}

Perekat pati dikelompokkan sebagai perekat alam dengan perekat dasar karbo- hidrat. Keuntungan penggunaan perekat pati antara lain : harga lebih murah, mudah pemakaiannya, dapat menghasilkan kekuatan rekat kering yang tinggi. Selain itu perekat pati juga memiliki kelemahan seperti : ketahanan terhadap air yang rendah untuk perekatan awal sehingga bersifat sementara (dalam kayu lapis), mudah diserang jamur, bakteri, dan binatang pemakan pati.

\section{METODOLOGI PENELITIAN Diagram alir penelitian}

Diagram alir penelitian dapat dilihat pada gambar 1. Secara terperinci diagram tersebut dapat dijelaskan sebagai berikut; Pengumpulan Dan Pengolahan Bahan Baku

1. Bahan Penelitian

- Batubara kualitas rendah (lignite) yang masih asli dan belum mengalami proses pengolahan.

- Sabut kelapa

- Bahan perekat yaitu tepung pati

- Batu kapur (limestone) sebagai bahan pengikat polutan

- Gas LPG, sebagai bahan bakar untuk memanaskan tungku pada proses pembakaran biobriket.

2. Pengolahan Bahan Baku

- Penghalusan batubara menjadi serbuk

- Pencacahan sabut kelapa menjadi serbuk

- Pembuatan bahan perekat

\section{Pembuatan Biobriket}

- Pencampuran bahan baku

Batu bara, sabut kelapa, bahan perekat dan lime stone dicampur hingga rata dengan komposisi batu bara : sabut kelapa $=10 \%: 90 \%, 20 \%: 80 \%, 30 \%: 70 \%$. (dalam hal ini prosentase bahan perekat dan limestone diabaikan dan dianggap homogen) 


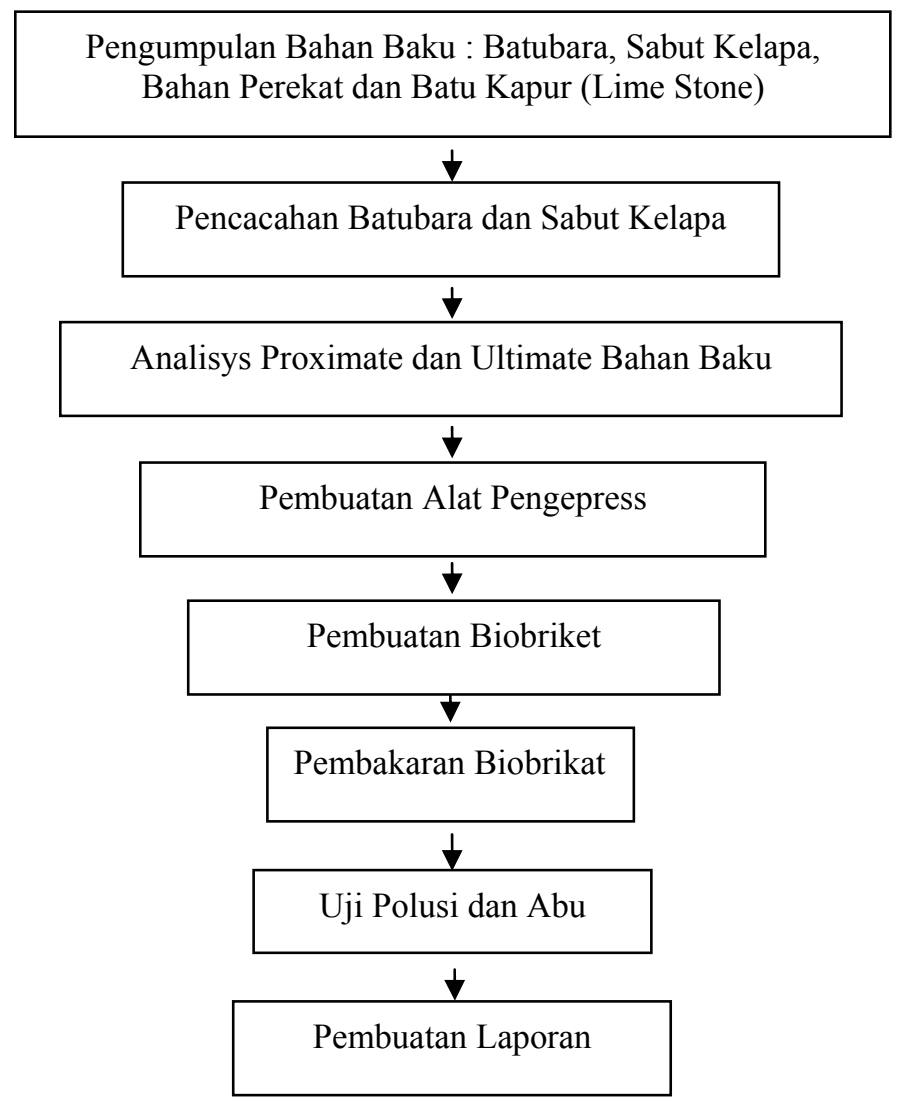

Gambar 1. Flowchart penelitian

- Pencetakan biobriket

Bahan baku yang telah tercampur rata dimasukkan ke dalam cetakan yang berbentuk silinder dengan diameter 1,5 $\mathrm{cm}$ dan tinggi $1,75 \mathrm{~cm}$.

- Pengepresan

Setelah bahan baku dimasukkan ke dalam cetakan, kemudian dilakukan pengepresan dengan tekanan 100 $\mathrm{kg} / \mathrm{cm}^{2}$ dan didiamkan selama 10 menit. Setelah itu biobriket dikeluarkan dari cetakan dan dikeringkan di tempat yang tidak terkena sinar matahari secara langsung selama 3 hari.

Bentuk biobriket yang dihasilkan dapat dilihat pada gambar 2

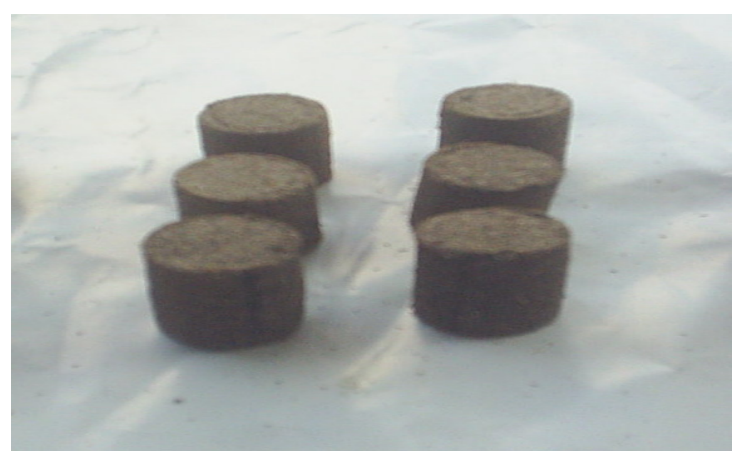

Gambar 2. Bentuk biobriket 


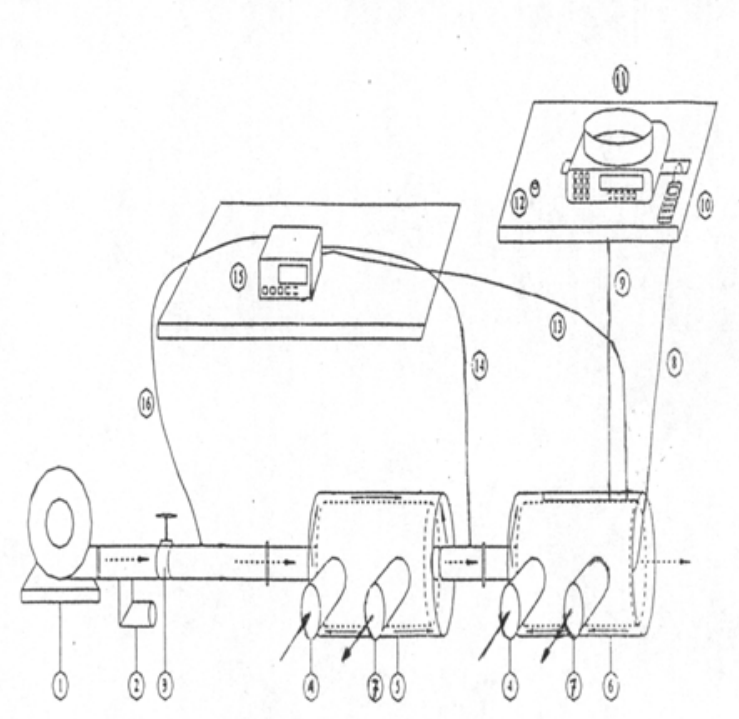

Keterangan :

$\rightarrow$ Aliran pemanas LPG

--- Aliran udara

1. Blower

2. Saluran by pass

3. Katup pengatur aliran udara

4. Saluran masuk pemanas LPG

5. Tungku 1

6. Tungku 2

7. Saluran buang pemanas LPG

8. Termakopel temperatur dinding

9. Kawat penggantung bahan bakar

10. Digital thermocouple reader

11. Electronic professional scale

12. Stop wacth

13. Termokopel temperatur gas pembakaran

14. Termokopel temperatur udara pre-heater

15.Digital thermocouple reader

16. Termokopel temperatur udara supply

\section{Gambar 3. Sketsa alat uji}

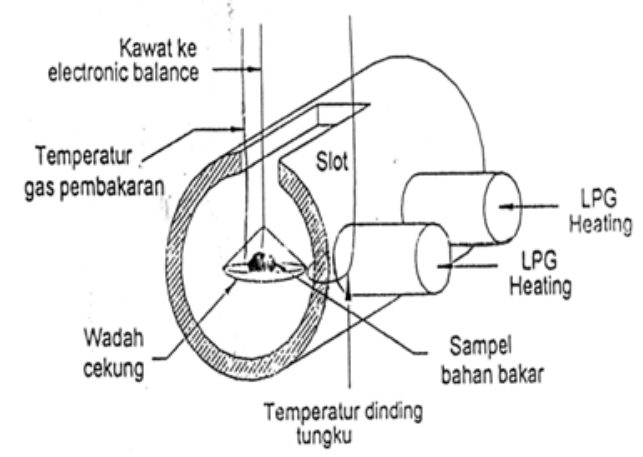

Gambar 4. Tempat Pembakaran biobriket

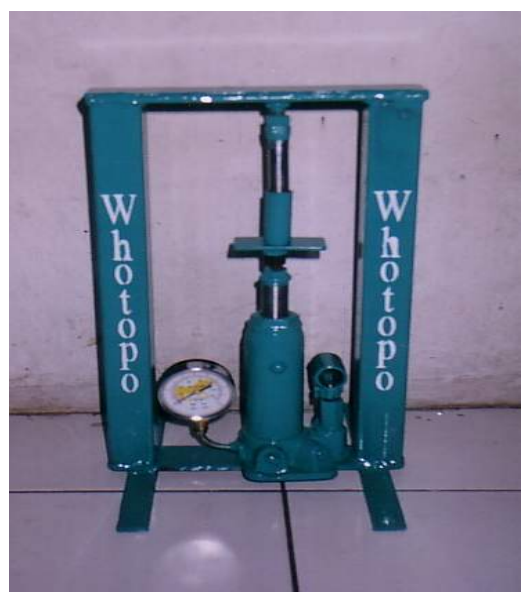

Gambar 5. Alat pengepress biobriket

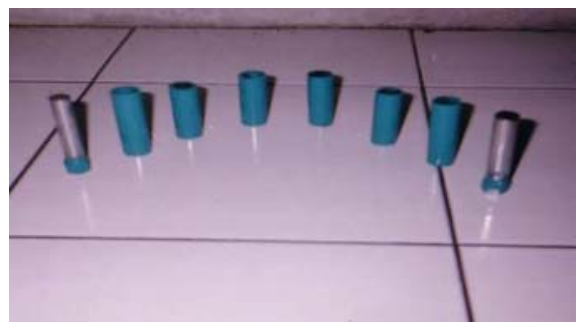

Gambar 6. Alat pencetak batubara 


\section{Peralatan Yang Digunakan}

Peralatan utama yang digunakan dalam penelitian ini terdapat di Laboratorium Teknik Mesin Universitas Muhammadiyah Surakarta

a. Alat Pembakaran Biobriket

Alat ini dapat dilihat pada gambar 3dan gambar 4.

b. Alat Pengepress biobriket

Alat pengepress biobriket dibuat deangan cara memodifikasi dongkrak hidraulik yang bertekanan maximal 2 ton dengan diameter $22 \mathrm{~mm}$ dan dipasang manometer pada saluran pembuangan udara dongkrak yang berfungsi untuk mengukur tekanan pada saat pengepresan. Selengkapnya alat dapat dilihat pada gambar 5 dan 6 .
HASIL DAN PEMBAHASAN

Hasil pengujian sifat dan bahan dasar dapat ditunujkkan pada tabel 1

Pengaruh Variasi Komposisi Terhadap Laju Pengurangan Massa Pada Pembakaran Biobriket (Batubara : Sabut Kelapa $=10 \%: 90 \%, 20 \%: 80 \%, 30 \%$ : 70\% )

Gambar 7 dan 8 menunjukkan laju pembakaran paling cepat adalah pada komposisi $90 \%$ sabut kelapa : $10 \%$ batubara, hal ini dipengaruhi oleh kandungan volatile matter biobriket. Semakin banyak kandungan volatile matter maka semakin mudah untuk terbakar dan menyala.

Tabel 1. Sifat-sifat bahan dasar

\begin{tabular}{|l|c|c|}
\hline \multicolumn{1}{|c|}{ Sifat } & Batu Bara Lignite & Sabut Kelapa \\
\hline Kadar air (\%) & 14,31 & 2,45 \\
\hline Kadar Abu (\%) & 2,02 & 1,34 \\
\hline Kadar Karbon (\%) & 69,53 & 21,62 \\
\hline Volatile Matter (\%) & 14,14 & 74,59 \\
\hline Nilai Kalor (Kal/Kg) & 5289,395 & 3942,751 \\
\hline
\end{tabular}

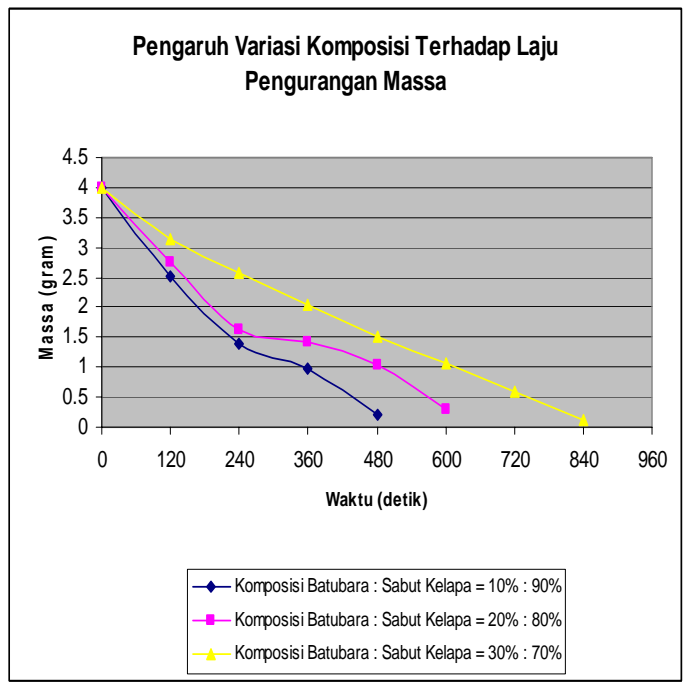

Gambar 7. Grafik pengurangan massa

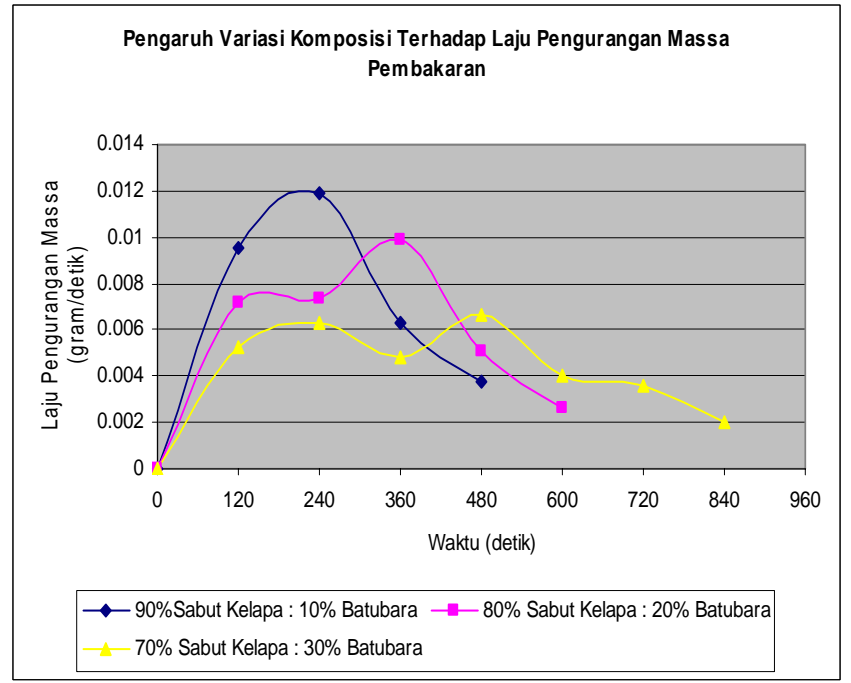

Gambar 8. Grafik laju pengurangan massa 


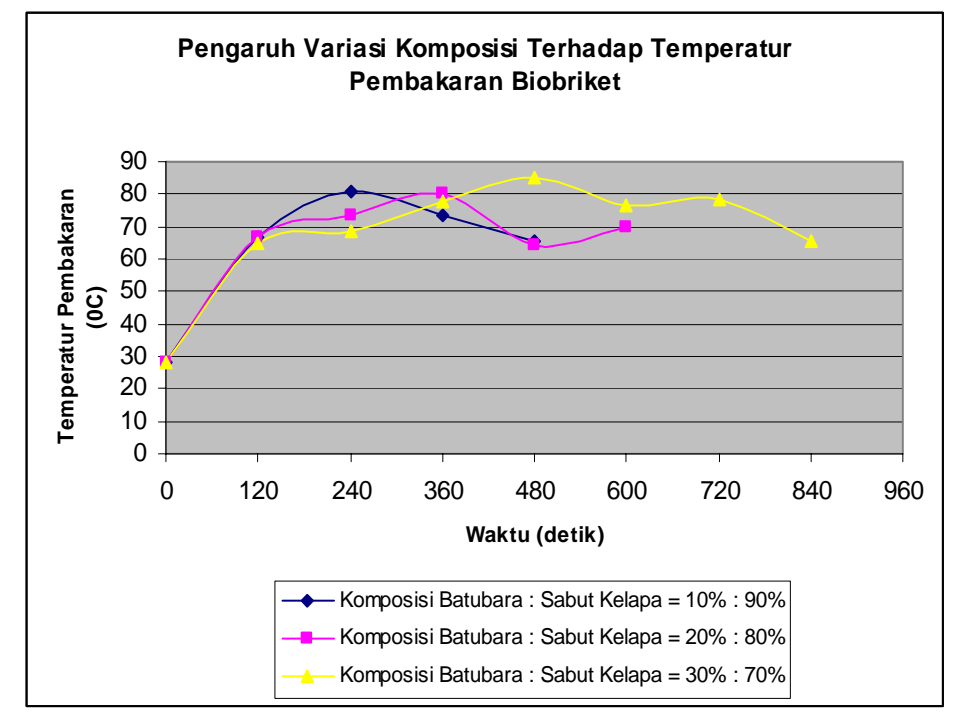

Gambar 9.Grafik temperature pembakaran

Pengaruh Variasi Komposisi Terhadap Temperatur Pembakaran Pada Pembakaran Biobriket (Batubara : Sabut Kelapa $=10 \%: 90 \%, 20 \%: 80 \%, 30 \%$ : 70\% )

Gambar 9 dapat dilihat bahwa temperatur pembakaran tertinggi terjadi pada proses pembakaran biobriket dengan komposisi $70 \%$ sabut kelapa : 30\% batubara, hal ini dipengaruhi oleh kandungan nilai kalor biobriket. Namun pencapaian suhu optimumnya cukup lama. Semakin besar berat jenis bahan bakar maka laju pembakaran akan semakin lama.

\section{Polutan Pembakaran Bahan Bakar}

Dari tabel 2 diatas dapat dilihat bahwa semakin besar prosentase biomass pada biobriket maka kandungan emisi polutan HC, CO dan NOx semakin berkurang. Dari ketiga variasi komposisi tersebut dapat disimpulakan bahwa biobriket yang paling rendah polutannya adalah biobriket dengan komposisi sabut kelapa : 10\% batubara.

Tabel 2. Polutan pembakaran biobriket

\begin{tabular}{|c|c|c|c|}
\hline KomposisiBatubara : Sabut Kelapa & \multicolumn{3}{|c|}{ Jenis Polutan } \\
\cline { 2 - 4 } & HC (\%) & CO (\%) & NO $_{\mathbf{x}} \mathbf{( \% )}$ \\
\hline $10 \%: 90 \%$ & 0.00010 & 0.0032 & 0.0040 \\
\hline $20 \%: 80 \%$ & 0.00012 & 0.0036 & 0.0041 \\
\hline $30 \%: 70 \%$ & 0.00014 & 0.0040 & 0.0044 \\
\hline
\end{tabular}

\section{KESIMPULAN}

1. Laju pembakaran biobriket paling cepat adalah pada komposisi $90 \%$ sabut kelapa : $10 \%$ batubara. Hal ini dipengaruhi oleh kandungan volatile matter yang terdapat pada biobriket. Semakin banyak kandungan volatile matter suatu biobriket maka semakin 
2. mudah biobriket tersebut terbakar, sehingga laju pembakaran semakin cepat.

3. Biobriket dengan tingkat polusi terendah adalah pada komposisi $90 \%$ sabut kelapa : $10 \%$ batubara. Semakin banyak kandungan karbon suatu biobriket maka semakin banyak polutan $\mathrm{CO}$ yang terjadi, semakin banyak kandungan biomass sabut kelapa pada biobriket akan menurunkan emisi polutan HC.
4. Penggunaan biobriket untuk kebutuhan sehari-hari sebaiknya digunakan biobriket dengan perbandingan komposisi $90 \%$ sabut kelapa : $10 \%$ sabut kelapa, karena tingkat polusinya paling rendah, pencapaian suhu optimum paling cepat dan pada kenyataannya pada pembakaran sehari hari tidak digunakan blower sebagai penyuplai udara, suplai udara hanya berasal dari udara alami.

\section{DAFTAR PUSTAKA}

Antolin,G.,Velasco,E.,Irusta,R.,Segovia,J.J.,1991, Combustion of Coffe Lignocellulose Waste, Proceedings of First Internasional Conference, Vilamoura, Portugal.

Naruse,I.,Gani,A.,Morishita,K.,2001,Fundamental Characteristic on Co-Combustion of Low Rank Coal with Biomass,Pittsburg.

Sudradjat, R., 2001, The Potensial of Biomass Energy Resources in Indonesia for the Possible Development of Clean Technology Process (CPT), Jakarta..

Joko, S,, 2005, Pengolahan Sampah Kota menjadi biobriket sebagai salah satu bahan bakar alternatif, UMS.

Samsul, M., 2004, Pengaruh Penambahan Arang Tempurung Kelapa Dan Penggunaan Perekat Terhadap Sifat-Sifat Fisika Dan Kimia Briket Arang Dari Arang serbuk Kayu Sengon, Universitas Gadjah Mada. 